\title{
DIETARY QUERCETIN SUPPLEMENTATION DOES NOT INCREASE MAXIMAL OXYGEN UPTAKE AND PHYSICAL WORK CAPACITY
}

E.C. Freese, kcureton@uga.edu

K.J. Cureton, kcureton@uga.edu, ORCID: 0000-0003-4917-6587

Department of Kinesiology, University of Georgia, Athens, GA

\begin{abstract}
Aim: The purpose of our study was to use a time-series design to investigate the effect of dietary quercetin supplementation on peak oxygen uptake (VO2peak) and physical work capacity. Methods and organization of the study: Nine recreationally-active men and women completed a treadmill-running graded exercise test (GXT) weekly (excepting wk 8) for 14 weeks. During the first 3 and last 3 weeks, no quercetin supplementation was administered. During weeks 4-11, subjects ingested four soft Q-chews (Nutravail Technologies) per day containing quercetin $(1 \mathrm{~g} / \mathrm{d})$, vitamin $\mathrm{C}$, vitamin $\mathrm{B} 3$ and folic acid. A control group of 5 men were also tested during the first and last week. Research results: $\mathrm{VO}_{2 \text { peak }}$ and test time remained stable throughout the 14 weeks at approximately $3.5 \pm 1.1 \mathrm{~L} / \mathrm{min}$ and $6 \pm 1.6 \mathrm{~min}$. Using a one-way repeated measures ANOVA, there was no significant difference among means $(P>0.05)$ for either measure. There was no trend for individual or mean values to increase above baseline during the treatment period. No changes occurred in the control group. Conclusions: We conclude that dietary quercetin supplementation with $1 \mathrm{~g} / \mathrm{d}$ for $8 \mathrm{wk}$ in non-endurance-trained men and women does not increase $\mathrm{VO}_{2 \text { peak }}$ or physical work capacity.
\end{abstract}

Keywords: exercise, flavonoids, muscle oxidative capacity, oxygen consumption

\section{ДОБАВЛЕНИЕ ДИЕТИЧЕСКОГО КВЕРЦЕТИНА НЕ ПРИВОДИТ К УВЕЛИЧЕНИЮ МАКСИМАЛЬНОГО ПОТРЕБЛЕНИЯ КИСЛОРОДА И ФИЗИЧЕСКОЙ РАБОТОСПОСОБНОСТИ}

Э.К. Фриз, К.Дж. Кьюретон

Университет Джорджии, Атенс-Кларк, США

\section{Аннотация}

Цель исследования - использовать построение динамических рядов для изучения влияния добавления диетического кверцетина на пиковое потребление кислорода (V.O2peak) и физическую работоспособность. Методы и организация исследования. Девять мужчин и женщин, занимающихся физической культурой, выполняли ступенчатый тест на беговой дорожке (GXT) еженедельно (за исключением недели 8) на протяжении 14 недель. В течение первых 3 и последних 3 недель не осуществлялось добавление кверцетина. В течение недель с 4-й по 11-ю тестируемые употребляли четыре мягких жевательных желе (Nutravail Technologies) с содержанием кверцетина в день (1 г/день), с витамином С, витамином В3 и фолиевой кислотой. Контрольная группа из 5 мужчин была также протестирована в течение первой и последней недель. Результаты исследования. Пиковое потребление кислорода и время тестирования сохранялись стабильными на протяжении 14 недель и составляли приблизительно $3.5 \pm 1.1$ л/мин и $6 \pm 1.6$ мин. При использовании односторонних повторных измерений ANOVA ни в одном случае не было отмечено существенной разницы между средними значениями $(\mathrm{P}>0.05)$. Не наблюдалось тенденции к увеличению относительно исходных показателей определенных или средних значений в период исследования. В контрольной группе не было отмечено никаких изменений. $\underline{3 \mathrm{a}-}$ ключение. Мы приходим к выводу о том, что добавление диетического кверцетина в объеме 1 г/день на протяжении 8 недель не приводит к увеличению пикового потребления кислорода или физической работоспособности у мужчин и женщин, не подготовленных к упражнениям на выносливость.

Ключевые слова: упражнение, флавоноиды, окислительная способность мышц.

\section{INTRODUCTION}

Quercetin (3,3', 4',5,7-pentahydroxyflavone) is a naturally-occurring dietary polyphenolic flavonoid found primarily in skins of fruits, leafy vegetables, and berries, as well as in black tea, red wine, and various fruit juices. National dietary assessments indicate that the mean intake of quercetin in the habitual diet typically varies from less than $5 \mathrm{mg}$ to $\sim 40 \mathrm{mg}$, but daily levels as high as 200-500 mg may be attained by heavy consum- 
ers of fruits and vegetables [11]. Quercetin has antioxidant, anti-carcinogenic, anti-inflammatory and cardio-protective properties [11], reduces the susceptibility to viral infection $[8,22]$, and decreases the risk of cancer and several chronic diseases [17]. Because of quercetin's healthful properties, it is marketed as a dietary supplement and added to foods and beverages.

Quercetin feedings stimulate mitochondrial biogenesis in mice. Davis et al. [7] found that one week of quercetin feedings increased mRNA of coactivators of mitochondrial biogenesis \{ sirtuin 1 (SIRT1) and peroxisome proliferator-activated receptor- $\gamma$ coactivator- 1 alpha (PGC- $1 \alpha)\}$, mitochondrial protein (cytochrome c) concentration and DNA in brain and skeletal muscle, and increased run time to exhaustion by $36-37 \%$ in sedentary mice. These findings are similar to those reported for another polyphenol, resveratrol [15]. Transgenic sedentary mice with increased skeletal muscle PGC- $1 \alpha$ exhibit greater mitochondrial content, peak rate of oxygen consumption, and exercise capacity compared with wild-type mice [3]. These studies on mice indicate that polyphenols such as quercetin and resveratrol have effects on skeletal muscle, aerobic capacity, and endurance that mimic those of exercise training [13], and have raised the possibility that they too may counter diseases related to mitochondrial dysfunction $[1,24]$ and may be ergogenic in humans. However, it remains to be established whether or not the adaptations to quercetin reported for mice are observed in humans.

Findings from the few research studies on the ergogenic effects of chronic $[2,16,19,20]$ and acute $[4,5]$ quercetin supplementation in humans are equivocal. Limited data also exist on the effect of quercetin supplementation on muscle oxidative capacity [20], V.O2peak, and substrate utilization during submaximal exercise, which would be expected to change consequent to mitochondrial biogenesis and contribute to increased endurance performance in humans with quercetin supplementation [13]. The studies of chronic quercetin supplementation on muscle oxidative capacity and performance were conducted on highly-trained cyclists and runners, who may have reached a ceiling for mitochondrial density due to their high level of aerobic training. Meta- analyses of studies in the literature have concluded that the effect of quercetin supplementation on $\mathrm{VO}_{2 \text { peak }}$ and endurance performance is small or trivial $[14,21,23]$. Additional study of the effect of quercetin supplementation on muscle oxidative capacity, $\mathrm{VO}_{2 \text { peak }}$, substrate utilization during exercise, and performance in untrained individuals who might experience an increase in muscle oxidative capacity is warranted.

The objective of our study was to investigate the effects of 8 wk of quercetin supplementation on $\mathrm{VO}_{\text {2peak }}$ and physical work capacity measured weekly in untrained men. It was hypothesized that dietary quercetin supplementation would increase $\mathrm{VO}_{2 \text { peak }}$ and physical work capacity measured during treadmill running in recreationallyactive men.

\section{METHODS}

Participants. Seventeen young, healthy, recreationally-active, but not endurance-trained, men and women were recruited to participated in the study. Untrained individuals were chosen as participants to increase the probability of detection of an effect of quercetin on skeletal muscle oxidative capacity, which has been shown to increase in sedentary mice [7] but not in highly-trained cyclists [20]. Men and women were selected for this study to get a heterogenous group. Participants signed an informed consent statement approved by the University's Institutional Review Board and were paid for participation.

Research design. A repeated -measures, time-series design was used for the study. Seventeen participants were initially recruited to participate. A random sample of 12 subjects was selected to serve in the experimental group, 9 of which completed all testing sessions. The remaining 5 served as a control group. It was anticipated that two participants may drop out of the experimental group, leaving a sample size of 10 for that group. No drop-out from the control group was anticipated. Outcome measures were obtained weekly for a 3-week baseline period, an 8-week treatment period, and a 3-week posttreatment period. During the treatment period, participants in the experimental group ingested $4 \mathrm{soft}$ Q-Force chews per day, 2 chews were ingested in the morning and 2 chews were ingested at night with meals, containing quercetin, Vitamin C, Vitamin B3, 
and folic acid. Total quercetin consumption for the experimental group was $1000 \mathrm{mg} /$ day. Subjects in the control group were evaluated for the outcome measures during the first and last week of the study and their diet was not supplemented with quercetin. Participants abstained from non-prescription drugs, vitamins, or other dietary supplements, but continued their normal diet and physical activity during the treatment period.

Treatment. Participants in the experimental group $(\mathrm{n}=9)$ ingested four individually-wrapped chews daily (two with breakfast, two with dinner) during the treatment period. The purpose of the multiple feedings was to maintain plasma quercetin levels throughout the day [18]. Each chew contained 250 mg quercetin, Vitamin C, Vitamin B3, and folic acid (Quercegen Pharma, Newton, MA). Participants in the control condition did not ingest chews. Participants turned in chew wrappers weekly to encourage treatment compliance.

Outcome measures. To determine the effect of dietary quercetin supplementation, experimental participants' maximal oxygen consumption and physical work capacity were tested for 14 consecutive weeks. During the graded treadmill test, subjects maximal HR, RPE, and RER were recorded as outcome variables. Subjects also completed a 7-day physical activity recall (7-D PAR) to test for changes in physical activity during the 14 weeks. Control participants were tested during the 1 st week and 14 th week of testing.

Preliminary measures. Participants attended a preliminary test session at which physical characteristics and body composition were assessed, and procedures used in assessment of outcome measures were practiced. Body height was measured using a wall stadiometer, body mass was determined using an electronic scale (model FW150KA1, A\&D Co., Ltd., Tokyo), and body composition was estimated using dual-energy $\mathrm{x}$-ray absorptiometry (iDXA, GE Healthcare-Lunar, Madison, WI).

$\underline{\mathrm{VO}}_{2 \text { peak }}$. Participants performed a graded treadmill running test to measure maximal oxygen uptake $\left(\mathrm{VO}_{2 \text { peak }}\right)$. A graded treadmill running test following the modified Astrand protocol was conducted to evaluate maximal oxygen uptake. After a 5-minute walking/jogging warm-up session at a self-selected comfortable intensity on a treadmill (Trackmaster, JAS Fitness System, Newton, KS), the speed was adjusted to either 7 miles per hour (men) or 6 miles per hour (female) and $0 \%$ grade. After each 2 -minute interval, the speed remained constant and the grade was increased by $2.5 \%$. The participants ran continuously and as long as possible, until he/she could no longer continue. Maximal oxygen uptake and related gas exchange measures were obtained by open-circuit spirometry using a PARVO Medics TrueOne 2400 Metabolic Measurement System (Parvo Medics, Inc., Salt Lake City, UT) and averaged over 1-minute intervals. Standard gases of known composition were used to calibrate the oxygen and carbon dioxide analyzers, and a 3-liter syringe was used to calibrate the pneumotachometer prior to each test session. HR and RPE were measured every 2 minutes and at the end of the $\mathrm{VO}_{2 \text { peak }}$ test. HR was measured with a Polar Vantage XL heart rate monitor (Polar Electro, Inc., Woodbury, NY, model 145900). RPE was measured by the Borg 15-point category scale.

$\underline{\text { Statistical analysis. Data are expressed as mean } \pm}$ SD. Differences between means were analyzed using a repeated measures one-way ANOVA for all experimental subjects for $\mathrm{VO}_{2 \text { peak }}$, total test time, $\mathrm{HR}_{\text {max }}, \mathrm{RER}_{\text {max }}, \mathrm{RPE}_{\text {max }}, 7$-day PAR. A paired t-test was used to assess the significance of differences between means for weeks 1 and 14 for the control group for $\mathrm{VO}_{2 \text { peak }}$, total test time, $\mathrm{HR}_{\text {max }}, \mathrm{RER}_{\text {max }}$, and $\mathrm{RPE}_{\text {max }}$. To assess changes before, during, and after the quercetin treatment, a paired t-test was used to determine changes in $\mathrm{VO}_{\text {2peak }}$ for the experimental group in weeks 3 vs. 4 , weeks 11 vs. 12 , mean of weeks 1-3 vs. 4-11, and mean of weeks 4-11 vs. 12-14.

\section{RESULTS}

Participants. Subject characteristics for the 9 participants in the experimental group and 5 participants in the control group who completed the study are summarized in Table 1 and show typical body composition for recreationally-active young adults and show no significant differences between the two groups.

Physiological Responses. Mean \pm SD individual peak responses for the 9 participants in $\mathrm{Q}$ across 13 weeks of testing and 5 participants in $C$ across 2 weeks of testing are summarized in Table 2. No sig- 
nificant changes in $\mathrm{HR}_{\max }, \mathrm{RPE}_{\max }, \mathrm{RER}_{\max }$, or total test time were found across testing weeks. The peak responses were typical of what is seen in a maximal aerobic test and suggests exhibited a max effort in each of the 13 tests.

Maximal Oxygen Consumption. Data related to individual changes in $\mathrm{VO}_{\text {2peak }}$ are shown in Table 2 and Figure 1. Supplementation in the quercetin group showed an average $\mathrm{VO}_{\text {2peak }}$ of $3.51 \pm 0.12$ $\mathrm{L} / \mathrm{min}$ and no statistical difference across weeks. Using a paired t-test, the control group showed no statistical difference across tests with a mean VO2peak of $3.53 \pm 0.05 \mathrm{~L} / \mathrm{min}$. There were no statistical differences in average weekly changes in $\mathrm{VO}_{2 \text { peak }}$ for the quercetin and control groups (Figure 2).

Physical Work Capacity. Average individual test time can be seen in Table 2. The quercetin and control group showed an average test time of $6.04 \pm 0.44 \mathrm{~min}$ and $6.2 \pm 0.68 \mathrm{~min}$ across all trials respectively. There were no statistical differences in individual changes in test time across weeks for the quercetin group, shown in Figure 3. Physical Activity Recall. There were no system- atic individual changes in physical activity recall across the 14 weeks of testing for the quercetin group $(\mathrm{p}=.353)$. Experimental participants reported an average of $269.8 \pm 11.9 \mathrm{kcal} / \mathrm{kg}^{*} \mathrm{wk}$ across all trials. The 7-D PAR of our participants shows that they would be considered a moderately active group of college-aged students [9].

\section{DISCUSSION}

The purpose of this investigation was to determine the influence of $8 \mathrm{wk}$ of quercetin supplementation on $\mathrm{VO}_{\text {2peak }}$ and physical work capacity in recreationally-active college-aged men and women. Our study showed there was no systematic increase in $\mathrm{VO}_{2 \text { peak }}$ or physical work capacity across 14 weeks of graded exercise testing. Therefore, our results do not support our hypothesis that 8 wk of quercetin supplementation would increase $\mathrm{VO}_{\text {2peak }}$ and physical work capacity.

For each of the 14 weeks of graded exercise testing, $\mathrm{VO}_{\text {2peak }}$ was defined as either a plateau in oxygen consumption with an increase in grade and/or 2 of

Table 1 - Mean \pm SD of subject characteristics

\begin{tabular}{|c|c|c|c|c|}
\hline Variable & $\begin{array}{l}\text { Quercetin Group } \\
(\mathrm{n}=9)\end{array}$ & Control Group $(n=5)$ & $\begin{array}{l}\text { Mean } \\
\text { Diff }\end{array}$ & $p$-value \\
\hline Age (yr) & $22.0 \pm 3.2$ & $20.8 \pm 0.8$ & 1.2 & 0.319 \\
\hline Height (cm) & $173.8 \pm 12.9$ & $173.0 \pm 7.3$ & 0.8 & 0.887 \\
\hline Mass - post $(\mathrm{kg})$ & $77.9 \pm 17.4$ & $77.4 \pm 10.3$ & 0.5 & 0.938 \\
\hline Fat-free mass - pre $(\mathrm{kg})$ & $58.5 \pm 17.1$ & $60.5 \pm 6.1$ & -2.0 & 0.775 \\
\hline Fat - post (\%) & $25.5 \pm 7.5$ & $22.2 \pm 3.9$ & 3.3 & 0.311 \\
\hline
\end{tabular}

Table 2 - Mean \pm SD of physiological responses to graded exercise testing across the 14 weeks

\begin{tabular}{|c|c|c|c|c|c|}
\hline $\begin{array}{c}\text { Subject } \\
\text { No. }\end{array}$ & $\mathrm{VO}_{2}(\mathrm{~L} / \mathrm{min})$ & Heart Rate (bpm) & RPE & RER & $\begin{array}{c}\text { Test Time } \\
\text { (min) }\end{array}$ \\
\hline \multicolumn{6}{|c|}{ Experimental Subjects } \\
\hline 1 & $2.67 \pm 0.09$ & $192.8 \pm 3.2$ & $18.2 \pm 1.8$ & $1.17 \pm 0.04$ & $6.14 \pm 0.48$ \\
\hline 2 & $5.03 \pm 0.14$ & $191.8 \pm 6.6$ & $18.5 \pm 1.7$ & $1.21 \pm 0.03$ & $6.43 \pm 0.40$ \\
\hline 3 & $3.93 \pm 0.12$ & $178.7 \pm 3.2$ & $19.1 \pm 0.9$ & $1.21 \pm 0.03$ & $8.22 \pm 0.27$ \\
\hline 4 & $4.83 \pm 0.06$ & $203.4 \pm 3.9$ & $19.8 \pm 0.4$ & $1.17 \pm 0.03$ & $7.86 \pm 0.50$ \\
\hline 5 & $2.45 \pm 0.11$ & $178.2 \pm 6.0$ & $18.5 \pm 1.1$ & $1.15 \pm 0.03$ & $6.8 \pm 0.49$ \\
\hline 6 & $3.89 \pm 0.12$ & $197.2 \pm 8.7$ & $19.0 \pm 0.0$ & $1.19 \pm 0.04$ & $4.66 \pm 0.40$ \\
\hline 7 & $3.70 \pm 0.20$ & $204.5 \pm 2.5$ & $18.7 \pm 1.3$ & $1.25 \pm 0.05$ & $6.11 \pm 0.63$ \\
\hline 8 & $3.25 \pm 0.10$ & $197.6 \pm 3.1$ & $19.6 \pm 0.7$ & $1.26 \pm 0.05$ & $5.04 \pm 0.52$ \\
\hline 9 & $1.76 \pm 0.10$ & $205.3 \pm 2.6$ & $16.8 \pm 0.8$ & $1.12 \pm 0.03$ & $3.12 \pm 0.27$ \\
\hline $\begin{array}{c}\text { AVG } \\
13 \text { Tests }\end{array}$ & $3.51 \pm 0.12$ & $194.4 \pm 4.4$ & $18.7 \pm 1.0$ & $1.19 \pm 0.04$ & $6.04 \pm 0.44$ \\
\hline \multicolumn{6}{|c|}{ Control Subjects } \\
\hline 1 & $3.09 \pm 0.01$ & $200.0 \pm 5.7$ & $20.0 \pm 0.0$ & $1.21 \pm 0.01$ & $6.49 \pm 0.07$ \\
\hline 2 & $3.91 \pm 0.11$ & $198.0 \pm 1.4$ & $20.0 \pm 0.0$ & $1.19 \pm 0.01$ & $6.32 \pm 2.63$ \\
\hline 3 & $3.5 \pm 0.07$ & $194.5 \pm 2.1$ & $19.5 \pm 0.7$ & $1.29 \pm 0.03$ & $6.41 \pm 0.05$ \\
\hline 4 & $3.62 \pm 0.05$ & $197.0 \pm 4.2$ & $20 \pm 0.0$ & $1.29 \pm 0.04$ & $6.18 \pm 0.21$ \\
\hline 5 & $3.52 \pm 0.03$ & $193.5 \pm 0.7$ & $15.5 \pm 0.7$ & $1.21 \pm 0.01$ & $5.71 \pm 0.43$ \\
\hline $\begin{array}{l}\text { AVG } \\
2 \text { Tests }\end{array}$ & $3.53 \pm 0.05$ & $196.6 \pm 2.8$ & $19.0 \pm 0.3$ & $1.24 \pm 0.02$ & $6.2 \pm 0.68$ \\
\hline
\end{tabular}


Individual Changes in VO2peak in the Experimental Group

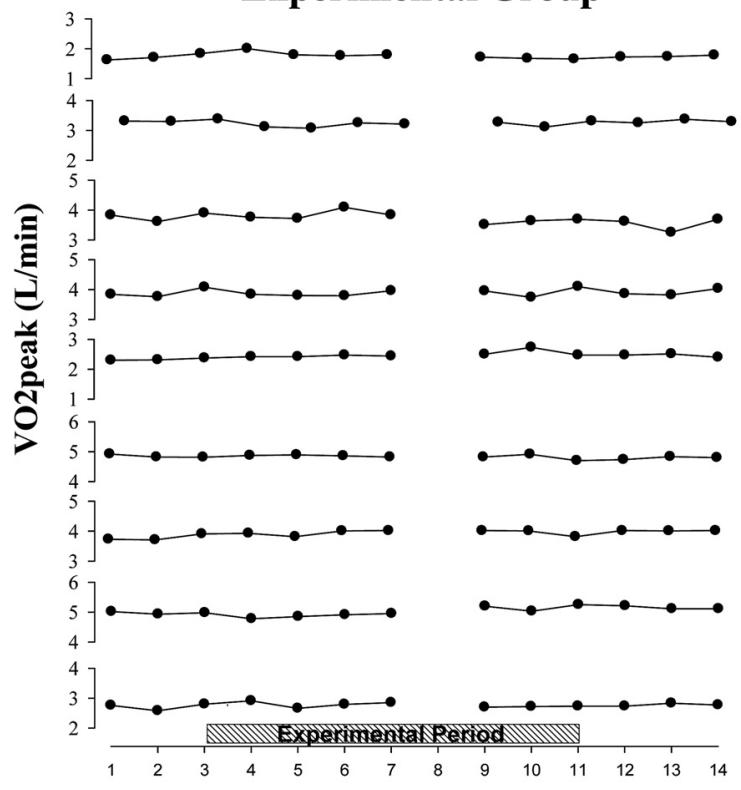

Test Number

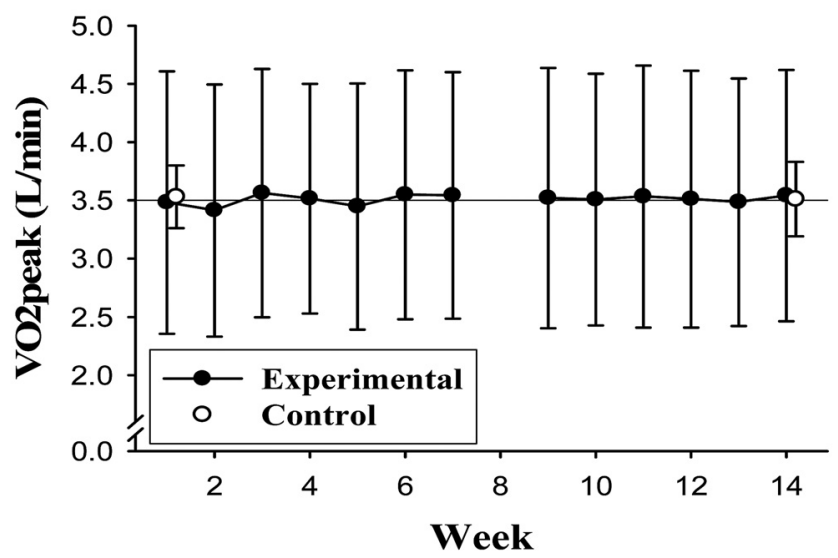

Figure 1 - Individual experimental changes in $\mathbf{V} . \mathrm{O}_{2 \text { peak }}$

Figure 2 - Average weekly changes in $\mathrm{VO}_{2 \text { peak }}$

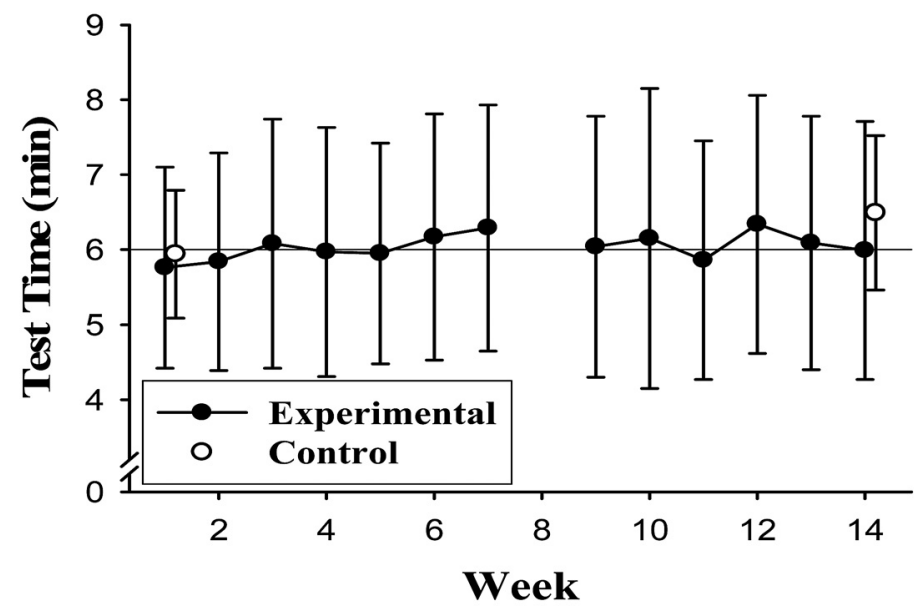

Figure 3 - Average weekly changes in physical work capacity 
the 3 conditions: RER greater than 1.1, RPE greater than or equal to 17 , and $\mathrm{HR}_{\text {max }}$ greater than 220 -age $\pm 10 \mathrm{bpm}$ (Table 2). Each subject exhibited a maximal effort during each graded exercise test.

Quercetin does have properties that have been shown in mice to cause an increase in mitochondrial biogenesis [7]. An increase in mitochondrial density in the working skeletal muscle would cause an increase in $\mathrm{VO}_{2 \text { peak }}$. In an in situ study where blood flow was kept constant across working skeletal muscle, trained rats showed greater oxygen consumption when compared to sedentary rats [17]. With an increase in mitochondrial density, as would be expected with quercetin supplementation, one would expect an increase in $\mathrm{A}-\mathrm{V} \mathrm{O}_{2}$ difference therefore causing an increase in $\mathrm{VO}_{\text {2peak }}$. Although reports on the effect of quercetin supplementation in humans have been equivocal, there has not been a study to our knowledge that has used repetitive $\mathrm{VO}_{2 \text { peak }}$ testing to investigate the time-course of any benefit. Our study shows there was no increase in $\mathrm{VO}_{\text {2peak }}$ across any of the 14 weeks of testing, including the 8 weeks of quercetin supplementation, nor was there a difference between the pre-supplementation to supplementation period. Davis et al. showed a $3.9 \%$ increase in $\mathrm{VO}_{2 \text { peak }}$ and a $13.2 \%$ increase in endurance capacity after 7 days of quercetin supplementation [6]. After 7 days of quercetin supplementation in our study, there was a decrease $\mathrm{VO}_{\text {2peak }}$ from 3.56 to $3.52 \mathrm{~L} / \mathrm{min}$.

Another possible benefit of quercetin has been findings showing an increase in voluntary physical activity. Mice given $25 \mathrm{mg} / \mathrm{kg} / \mathrm{d}$ of quercetin showed a significant increase in voluntary wheel running activity [7]. Using the 7-D PAR, our study showed that there is no such benefit in humans. Across the 14 weeks of testing, participants averaged $269.8 \pm 11.9 \mathrm{kcal} / \mathrm{kg}^{*} \mathrm{wk}$ and saw no increase in voluntary physical activity.

\section{REFERENCES}

1. Baur J.A, Pearson KJ, Price N.L, Jamieson H.A, Lerin C, Kalra A, Prabhu V.V, Allard J.S, Lopez-Lluch G., Lewis K., Pistell PJ., Poosala S., Becker K.G., Boss O., Gwinn D., Wang M., Ramaswamy S., Fishbein K.W., Spencer R.G., Lakatta E.G., Le Couteur D., Shaw RJ., Navas P., Puigserver P., Ingram D.K., de Cabo R., Sinclair D.A. Resveratrol improves health and survival of mice on a high-calorie diet. Nature, 2006, vol. 444, pp. 337-342.

2. Bigelman K.A, Fan E.H, Chapman D.P., Freese E.C., Trilk J.L., Cureton KJ. Effects of six weeks of quercetin supplementation on physical performance in ROTC cadets. Military
Other studies reporting null findings suggest it may be due to inadequate treatment time $[5,10]$, but following 6-weeks of quercetin training, a group of Army ROTC cadets showed no improvement in $\mathrm{VO}_{2 \text { peak }}$ [2]. To our knowledge, our study is the longest treatment of quercetin to date and failed to show an improvement in $\mathrm{VO}_{2 \text { peak }}$ or physical work capacity. Mitochondrial adaptations and increases in $\mathrm{VO}_{2 \text { peak }}$ to aerobic training typically take $\sim 6$ wk [12], shorter than the duration of supplementation in our study. It would be expected that an increase in aerobic capacity associated with mitochondrial density would be seen following 8 wk of quercetin supplementation.

Failure to find an ergogenic effect in our study could be due to the interaction of quercetin and dietary intake of our subjects. Diet was not controlled for our subjects, meaning quercetin intake could have been different across all subjects depending on the amount of fruits and vegetables consumed. Future studies should include control of fruits and vegetables consumed by the subjects to test for such an interaction.

\section{CONCLUSIONS}

We conclude that 8 wk of quercetin supplementation does not increase $\mathrm{V} . \mathrm{O}_{\text {2peak }}$ or physical work capacity in recreationally-active college-aged men and women. The null findings of our study suggest that exercise capacity benefits of quercetin supplementation found in mice should not be generalized to humans.

\section{DISCLOSURE}

Author Eric Freese was affiliated with the University of Georgia, Athens, GA, at the time of data collection and is currently employed by the Gatorade Sports Science Institute, a division of PepsiCo,Inc.

Medicine, 2010, vol.175, pp.791-798.

3. Calvo J.A., Daniels T.G., Wang X., Paul A., Lin J., Spiegelman B.M., Stevenson S.C., Rangwala S.M. Muscle-specific expression of PPARgamma coactivator-1alpha improves exercise performance and increases peak oxygen uptake. Journal of Applied Physiology, 2008, vol. 104, pp. 13041312.

4. Cheuvront S.N., Ely B.R., Kenefick R.W., Michniak-Kohn B.B., Rood J.C., Sawka M.N. No effect of nutritional adenosine receptor antagonists on exercise performance in the heat. American Journal of Physiology - Regulatory, Integrative and Comparative Physiology, 2009, vol. 296, pp. R394-401. 
5. Cureton KJ., Tomporowski P.D., Singhal A., Pasley J.D., Bigelman K.A., Lambourne K., Trilk J.L., McCully K.K., Arnaud MJ., Zhao $\mathrm{O}$. Dietary quercetin supplementation is not ergogenic in untrained men. Journal of Applied Physiology, 2009, vol. 107, pp. 1095-1104.

6. Davis J.M., Carlstedt CJ., Chen S., Carmichael M.D., Murphy E.A. The Dietary Flavonoid Quercetin Increases VO2max and Endurance Capacity. International Journal of Sport Nutrition and Exercise Metabolism, 2010, vol. 20, pp. 5662.

7. Davis J.M., Murphy E.A., Carmichael M.D., Davis B. Quercetin increases brain and muscle mitochondrial biogenesis and exercise tolerance. American Journal of Physiology - Regulatory, Integrative and Comparative Physiology, 2009, vol. 296, pp. R1071-1077.

8. de Boer V.C., Dihal A.A., van der Woude H., Arts I.C., Wolffram S., Alink G.M., Rietjens I.M., Keijer J., Hollman P.C. Tissue distribution of quercetin in rats and pigs. Journal of Nutrition, 2005, vol. 135, pp. 1718-1725.

9. Dishman R.K., Steinhardt M. Reliability and concurrent validity for a 7-d re-call of physical activity in college students. Medicine and Science in Sports and Exercise, 1988, vol. 20, pp. 14-25.

10. Ganio M.S., Armstrong L.E., Johnson E.C., Klau J.F., Ballard K.D., Michniak-Kohn B., Kaushik D., Maresh C.M. Effect of quercetin supplementation on maximal oxygen uptake in men and women. Journal of Sports Sciences, 2010, vol. 28, pp. 1-8.

11. Harwood M., Danielewska-Nikiel B., Borzelleca J.F., Flamm G.W., Williams G.M., Lines T.C. A critical review of the data related to the safety of quercetin and lack of evidence of in vivo toxicity, including lack of genotoxic/ carcinogenic properties. Food and Chemical Toxicology, 2007 , vol. 45, pp. $2179-2205$.

12. Henriksson J., Reitman J.S. Time course of changes in human skeletal muscle succinate dehydrogenase and cytochrome oxidase activities and maximal oxygen uptake with physical activity and inactivity. Acta Physiologica Scandinavica, 1977, vol. 99, pp. 91-97.

13. Holloszy J.O., Coyle E.F. Adaptations of skeletal muscle to endurance exercise and their metabolic consequences. Journal of Applied Physiology, 1984, vol. 56, pp. 831 838.

14. Kressler J., Millard-Stafford M., Warren G.L. Quercetin and endurance exercise capacity: a systematic review and meta-analysis. Medicine and Science in Sports and Exercise, 2011, vol. 43, pp. 2396-2404.
15. Lagouge M., Argmann C., Gerhart-Hines Z., Meziane H., Lerin C., Daussin F., Messadeq N., Milne J., Lambert P., ElLiott P., Geny B., Laakso M., Puigserver P., Auwerx J. Resveratrol improves mitochondrial function and protects against metabolic disease by activating SIRT1 and PGC-1alpha. Cell, 2006,vol. 127, pp. 1109-1122.

16. MacRae H.S., Mefferd K.M.Dietary antioxidant supplementation combined with quercetin improves cycling time trial performance. International Journal of Sport Nutrition and Exercise Metabolism, 2006, vol. 16, pp. 405-419.

17. McAllister R.M., Terjung R.L. Training-induced muscle adaptations: increased performance and oxygen consumption. Journal of Applied Physiology, 1991, vol. 70, pp.15691574.

18. Moon YJ., Wang L., DiCenzo R., Morris M.E. Quercetin pharmacokinetics in humans. Biopharmaceutics and Drug Disposition, 2008, vol. 29, pp. 205-217.

19. Nieman D.C., Henson D.A., Davis J.M., Dumke C.L., Gross SJ.,Jenkins D.P., Murphy E.A., Carmichael M.D., Quindry J.C. McAnulty S.R., McAnulty L.S., Utter A.C., Mayer E.P. Quercetin ingestion does not alter cytokine changes in athletes competing in the Western States endurance run.Journal of Interferon and Cytokine Research, 2007, vol. 27, pp. 10031011.

20. Nieman D.C., Henson D.A., Maxwell K.R., Williams A.S., McAnulty S.R., Jin F., Shanely R.A., Lines T.C. Effects of quercetin and EGCG on mitochondrial biogenesis and immunity. Medicine and Science in Sports and Exercise, 2009, vol. 41, pp. 1467-1475.

21. Pelletier D.M., Lacerte G., Goulet E.D.B. Effects of Quercetin Supplementation on Endurance Performance and Maximal Oxygen Consumption: A Meta-Analysis. International Journal of Sport Nutrition and Exercise Metabolism, 2013, vol. 23, pp. 73-82.

22. Ristow M., Zarse K., Oberbach A., Kloting N., Birringer M., Kiehntopf M., Stumvoll M., Kahn C.R., Bluher M. Antioxidants prevent health-promoting effects of physical exercise in humans. Proceedings of the National Academy of Sciences of the United States of America, 2009, vol. 106, pp. 8665-8670.

23. Somerville V., Bringans C., Braakhuis A. Polyphenols and Performance: A Systematic Review and Meta-Analysis. Sports Medicine, 2017, vol. 47, pp. 1589-1599.

24. Tarnopolsky M.A., Raha S. Mitochondrial myopathies: diagnosis, exercise intolerance, and treatment options. Medicine and Science in Sports and Exercise, 2005, vol. 37, pp. 2086-2093.

\section{CONTACT INFORMATION:}

Kirk J. Cureton - Department of Kinesiology, Ramsey Center, 330 River Road, University of Georgia, Athens, GA 30602 6554; e-mail: kcureton@uga.edu; ORCID: 0000-0003-4917-6587.

Поступила в редакцию 12 октября 2019 г.

\section{ОБРАЗЕЦ ЦИТИРОВАНИЯ}

Freese, E.C. Dietary quercetin supplementation does not increase maximal oxygen uptake and physical work capacity / E.C. Freese, KJ. Cureton // Наука и спорт: современные тенденции. - 2019. - Т. 7, № 4. - C. 12-18. DOI: 10.36028/2308-8826-2019-7-4-12-18

\section{FOR CITATION}

Freese E.C., Cureton K.J. Dietary quercetin supplementation does not increase maximal oxygen uptake and physical work capacity. Science and sport: current trends, 2019, vol. 7, no. 4, pp. 12-18 (in Russ.) DOI: 10.36028/2308-8826-2019-7-4-12-18 